\title{
Effects of Fe-soy Proteinate Chelate Supplementation to Diets of Periparturient Sows and Piglets on the Fe Level in the Blood of Piglets
}

\author{
Sun Jae $\mathrm{Im}^{1}$, Myung Geol Pang ${ }^{1}$, Kwang Suk Shin ${ }^{1}$, Ah Reum Rhee ${ }^{1}$, T. A. Ebeid ${ }^{2}$ \\ and In Kee Paik ${ }^{1}$. \\ ${ }^{1}$ Department of Animal Science and Technology, Chung-Ang University, \\ ${ }^{2}$ Department of Poultry Production, Faculty of Agriculture, Kafrelsheikh University, 33516 Kafr El-Sheikh, Egypt
}

\begin{abstract}
The objective of the present study was to investigate the effects of Fe-soy proteinate chelate (Fe-SP) on sows milk, piglet blood parameters and performance. A total of 15 sows of $3 \mathrm{wk}$ before parturition and pigs after births to 3 wk were assigned to three dietary treatments: control (sow-basal diet, piglets with Fe injection); Fe-SP 100 (Fe 100 ppm as Fe-SP in sow and piglet diet); Fe-SP 200 (Fe 200 ppm as Fe-SP in sow and piglet diet). Each treatment had 5 replicates (sows) of six piglets per sow randomly selected from the same offspring. For this experiment, Fe-SP was manufactured. There were no significant differences among treatments in number of pigs born in total or alive per litter, birth weight, number of pigs weaned per litter and weaning weight. However, weight gain, feed intake and feed conversion ratio significantly $(\mathrm{p}<0.05)$ decreased as the supplementation level of Fe-SP increased. There were no significant differences among treatments in Fe content at 3 wk before parturition in sow blood. However, Fe content at 2 wk before parturition in sow blood significantly $(\mathrm{p}<0.05)$ increased as the supplementation of Fe-SP. While there were no significant differences among treatments in Fe content at 1 wk before parturition in sow blood, it tended to increase as the supplementation level of Fe-SP increased. There were no significant differences among treatments in Fe content of sow milk. However, it tended to increase as the supplementation level of Fe-SP increased. Iron content in the blood of piglets was significantly $(\mathrm{p}<0.05)$ higher in control (Fe injected) than Fe-SP 100 and Fe-SP 200 treatments at $1^{\text {st }}$ and $2^{\text {nd }}$ wk but it was significantly higher in Fe-SP 200 than others in $3^{\text {rd }}$ wk. Zinc content in the blood also significantly $(p<0.05)$ increased as the Fe-SP supplementation level increased in $3^{\text {rd }}$ wk. In conclusion, Fe-SP supplementation significantly affected Fe content in the blood of piglets. Iron injection was more effective at $1^{\text {st }}$ and $2^{\text {nd }}$ wk, while Fe-SP 200 supplementation was effective at $3^{\text {rd }}$ wk in improving blood Fe level in piglets.
\end{abstract}

(Key words : Fe-soy proteinate, Iron injection, Blood Fe, Piglets, Iron in sow milk)

\section{INTRODUCTION}

Iron $(\mathrm{Fe})$ is an essential biological element for livestock as well as human beings (Georgievskii et al., 1982). Nutritional or Fe-deficiency anemia has long been a paramount concern in the swine industry. The intramuscular injection of iron preparations to piglets for prevention of anemia has become an accepted practice. Other iron preparations including peptonized iron (Wahlstrom and Juhl, 1960; Becker et al., 1960), ferric ammonium citrate (Becker et al., 1960; Doornenbal, 1959) or ferric phosphate (Barber et al., 1955; Brownlie, 1955) have produced generally inferior results (Pond et al., 1961). Iron content shows minimum variability with dietary change (Naber, 1979). Researches on organic minerals have been actively undertaken because chelate minerals can be more effectively absorbed into the intestines than inorganic oxide and sulfate (Wedekind et al., 1992; Aoyagi and Baker, 1993). Fe may have a big difference in bioavailability according to its form of supply. Chelate minerals which are new organic compounds of the metal enhanced the productivity of livestock because they have a higher bioavailability than inorganic minerals (Kratzer and Vohra, 1986). Organic minerals, in particular, amino acids and low molecule peptide (Miller et al., 1972; McNaughton et al., 1974; Zoubek et al., 1975; Spears, 1992) in the state of chelation with metal ions were more effectively absorbed than inorganic in the body (Fouad, 1976; Ashmead, 1993). It was demonstrated that the $\mathrm{Fe}$ content of piglet blood was increased due to supplementation with organic Fe supplements (Ashmead, 1993). The provision of iron to the sow for

* Corresponding author: Dr. In Kee Paik, Department of Animal Science and Technology, Chung-Ang University, Ansung-si, Kyonggi-do 456- 756, South Korea. Tel: +82-31-670-3028, Fax: +82-31-676-2196, E-mail: ikpaik@cau.ac.kr 
subsequent transfer to her offspring could improve convenience and, perhaps, economy if the cost were sufficiently low (Brady et al., 1978).

Therefore, an experiment was conducted to investigate whether Fe-SP supplementations are comparable to recent accepted practice, i.e., intramuscular injection of iron preparations.

\section{MATERIALS AND METHODS}

\section{Animals and diets}

A total of 15 sows (Landrace and Yorkshire) of three wk before parturition and 90 pigs (Landrace, Yorkshire and Duroc) after birth to three wk were assigned to three dietary treatments: control (sow-basal diet, piglets with Fe injection 3 d after birth); Fe-SP 100 (Fe 100 ppm as Fe-SP in sow and piglet diet); Fe-SP 200 (Fe 200 ppm as Fe-SP in sow and piglet diet). The sows used in this experiment were not in same parity because $\mathrm{Fe}$ metabolism of sow was not significantly influenced by parity in a previous experiment. Each treatment had five replicates (sows) of six piglets per sow; six randomly selected from the same offspring. Piglets of control group were intramuscularly injected with $100 \mathrm{mg}$ of slow release $\mathrm{Fe}$ as Fe dextran $\left(\right.$ Ferriaid $^{\circledR}$ : Bomac Laboratories Ltd., Newzealand) $3 \mathrm{~d}$ after birth. The Fe-SP used in this experiment was manufactured by the method of Seo et al. (2010). Diets of sows and piglets were prepared in mash form. Fe-SP was supplemented by top dressing in sow and by mixing with diets in piglets. Feed and water were given ad libitum during the experimental period. The total feeding trial period was six weeks for sow (3wk before and $3 \mathrm{wk}$ after parturition) and $3 \mathrm{wk}$ for piglets after birth. The compositions of the control basal diets are shown in Table 1 (sow diet) and Table 2 (prestarter diet) which were analyzed by AOAC (1990) method.

\section{Feeding of experimental animals}

Feeding and handling procedures were performed following the guidelines for the ethical treatment of animals, which is described in the Regulation of Chung-Ang University (AEC20080428-2). The average indoor temperature of the barn during the experimental period was $21^{\circ} \mathrm{C}$ and sows and piglets were provided with programmed feeding and ventilation.

To assess piglet performance, total number of born and
Table 1. Composition and nutrient content of the basal sow diet

\begin{tabular}{lc}
\hline Item & Amount \\
\hline \hline Ingredients, \% & $\% \cdots \cdots \cdots$ \\
Corn, US No. 3 & 40.982 \\
Wheat, ground & 13.000 \\
Wheat meal & 1.600 \\
Soybean meal, 44\% & 13.600 \\
Rapeseed meal & 2.000 \\
Rice bran & 5.000 \\
DDGS & 12.000 \\
Animal fat & 4.000 \\
Molasses & 4.000 \\
Dicalcium phosphate & 0.800 \\
Limestone & 1.400 \\
Additive matrial & 0.323 \\
Salt & 0.500 \\
Lysine-78\% & 0.423 \\
Threonine-99\% & 0.053 \\
Methionine-99\% & 0.049 \\
Premix ${ }^{1)}$ & 0.270 \\
\hline Total & 100.000 \\
\hline Nutrient ${ }^{2)}$ & \\
ME, kcal/kg & $3,420.000$ \\
CP, \% & 16.650 \\
Crude fat, \% & 7.880 \\
Crude ash, \% & 6.100 \\
Ca, \% & 0.870 \\
Available P, \% & 0.600 \\
Lys, \% & 1.030 \\
Met, \% & 0.310 \\
The, \% & 0.650 \\
Zn, g / kg & 0.045 \\
Fe, g / kg & 0.090 \\
\hline
\end{tabular}

${ }^{1)}$ Premix contains followings per kg diet: Vitamin A, 10,000 IU; Vitamin $\mathrm{D}_{3}, 2,000 \mathrm{IU}$; Vitamin E, $67 \mathrm{IU}$; Vitamin $\mathrm{K}_{3}, 3,000 \mathrm{mg}$; Vitamin $B_{1}, 2,000 \mathrm{mg}$; Vitamin $B_{2}, 10,000 \mathrm{mg}$; Vitamin $B_{6}$, 5,000 mg; Phantothenic acid, 30,000mg; Folic acid, 2,500 mg; Biotin, $300 \mathrm{mg}$; Choline, $540 \mathrm{mg}$; Cyanocob, $30 \mathrm{mg}$; Zn, 45,000 mg; Mn, 33,333 mg; Fe, 90,000 mg; Cu, 8,000 mg; Co, 200 mg; I, 500 mg; Se, $200 \mathrm{mg}$.

${ }^{2)}$ Calculated values according to NRC (1998).

alive pigs per litter, birth weight, total number of weaned pigs per litter, and weaning weight were recorded. Feed intake was measured weekly, and then feed conversion ratio was calculated.

\section{Sampling and analysis}

Milk samples from sows were collected three days after 
Table 2. Composition and nutrient content of the basal piglet diet

\begin{tabular}{lc}
\hline Item & Amount \\
\hline \hline Ingredients, \% & \%.......... $\%$ \\
Corn, US No.3 & 20.800 \\
Milk replacer & 15.000 \\
Wheat meal & 12.000 \\
Soybean meal, 44\% & 16.700 \\
Cookies meal & 10.000 \\
Gluten feed & 4.200 \\
Soy protein & 5.000 \\
Plasm protein & 2.000 \\
Soy oil & 4.000 \\
Sugar & 5.000 \\
Monocalcium phophate & 1.200 \\
Limestone & 0.400 \\
Additive matrial & 2.492 \\
Salt & 0.100 \\
Lysine-78\% & 0.427 \\
Threonine-99\% & 0.066 \\
Methionine-99\% & 0.180 \\
Choline & 0.120 \\
Premix ${ }^{1)}$ & 0.315 \\
\hline Total & 100.000 \\
\hline Nutrient ${ }^{2}$ & $3,640.000$ \\
ME, kcal/kg & 21.560 \\
CP, \% & 7.180 \\
Crude fat, \% & 5.290 \\
Crude ash, \% & 0.740 \\
Ca, \% & 0.700 \\
Available P, \% & 1.430 \\
Lys, \% & 0.500 \\
Met, \% & 0.900 \\
The, \% & 0.030 \\
Zn, g / kg & 0.130 \\
Fe, g / kg & \\
\hline
\end{tabular}

${ }^{1)}$ Premix contains followings per kg diet: Vitamin A, 10,000 IU; Vitamin $\mathrm{D}_{3}$, 2,000 IU; Vitamin E, $67 \mathrm{IU}$; Vitamin $\mathrm{K}_{3}, 3,000 \mathrm{mg}$; Vitamin $\mathrm{B}_{1}, 2,000 \mathrm{mg}$; Vitamin $\mathrm{B}_{2}, 10,000 \mathrm{mg}$; Vitamin $\mathrm{B}_{6}$, 5,000 mg; Phantothenic acid, 30,000mg; Folic acid, 2,500 mg; Biotin, $300 \mathrm{mg}$; Choline, $540 \mathrm{mg}$; Cyanocob, $30 \mathrm{mg}$; Zn, 30,000 mg; Mn, 50,000 mg; Fe, 130,000 mg; Cu, 8,000 mg; Co, 300 mg; I, $800 \mathrm{mg}$; Se, $300 \mathrm{mg}$.

${ }^{2)}$ Calculated values according to NRC (1998).

parturition to measure $\mathrm{Fe}$ content. Blood samples were collected every week from the jugular vein of sows and piglets into EDTA-treated vaccutainers (each $5 \mathrm{~mL}$ ). In order to measure mineral contents, $0.5 \mathrm{~mL}$ of whole blood sample was treated with $2 \mathrm{~mL}$ of nitric acid and $0.2 \mathrm{~mL}$ of hydrogen peroxide in a closed vessel digestion system
(START D, Milestone, Italy) and digested for 8 minutes (300 W, $5 \mathrm{~min}+600 \mathrm{~W}, 3 \mathrm{~min})$. Mineral contents (Fe, $\mathrm{Cu}$ and $\mathrm{Zn})$ in the blood of sows and piglets were measured using ICP spectrometer (Optima 5300DV, PerkinElmer, USA).

\section{Preparation of Fe-SP and Measurement of FT-IR and XRD spectra}

Soy digest was produced by hydrolysis of $100 \mathrm{~g}$ soybean meal (44\% CP) in $500 \mathrm{~mL}$ distilled water with $2 \mathrm{~mL} 28 \%$ hydrogen peroxide (DC Chemical Co. Ltd., Korea) for $2 \mathrm{~h}$. Two milliliters Alcalase 2.4 L (NovoNordisk, Denmark) was then added for further hydrolysis at $\mathrm{pH} 8,60^{\circ} \mathrm{C}$ for $2 \mathrm{~h}$. An iron solution was prepared by dissolving $100 \mathrm{~g} \mathrm{FeSO}_{4}$. $7 \mathrm{H}_{2} \mathrm{O}$ in $200 \mathrm{~mL}$ distilled water. Fe-soy proteinate was produced by mixing soy digest and Fe solution with $50 \mathrm{~mL}$ $50 \% \mathrm{NaOH}$. The precipitate was separated, dried in an oven at $30^{\circ} \mathrm{C}$ for two days and then crushed into powder. The prepared Fe-SP was verified to contain approximately 20\% Fe by analysis with an ICP spectrometer (Optima 5300DV, PerkinElmer, USA).

To confirm whether prepared Fe-SP is appropriate, the infrared (IR) and X-ray diffractometer (XRD) spectra were performed. FT-IR (Fourier transform infrared) and XRD (Xray diffraction) spectra of Fe-SP were measured. The FT-IR spectra were obtained on a Shimadzu spectrometer (FT-IR 8400S, Shimadzu Co. Ltd., Japan) with a resolution of $4 \mathrm{~cm}^{-1}$, and XRD scattering spectra were measured by an X-ray diffractometer (Dmax 2000, Rigaku Co., Japan). For the XRD measurements, the wavelength of the Mo X-ray was 1.5418 $\AA$ with a scan range of $5^{\circ}<2 \theta<70^{\circ}$ at $30 \mathrm{~mA}$ and $35 \mathrm{kV}$ (Han et al., 2006).

\section{Statistical analysis}

Data were subjected to analysis of variance using the GLM (SAS Institute, 2000). Significant differences among the treatments were measured using Duncan's multiple range test at $\mathrm{p}<0.05$ (Steel and Torrie, 1980).

\section{RESULTS AND DISCUSSION}

The IR and XRD spectra of Fe-SP are shown in Fig. 1 and Fig. 2, respectively. They were similar to those of Seo et al. (2010). In the IR spectra of Fe-SP, the $\mathrm{C}=\mathrm{O}$ stretching frequency significantly shifted to a higher energy, indicating 


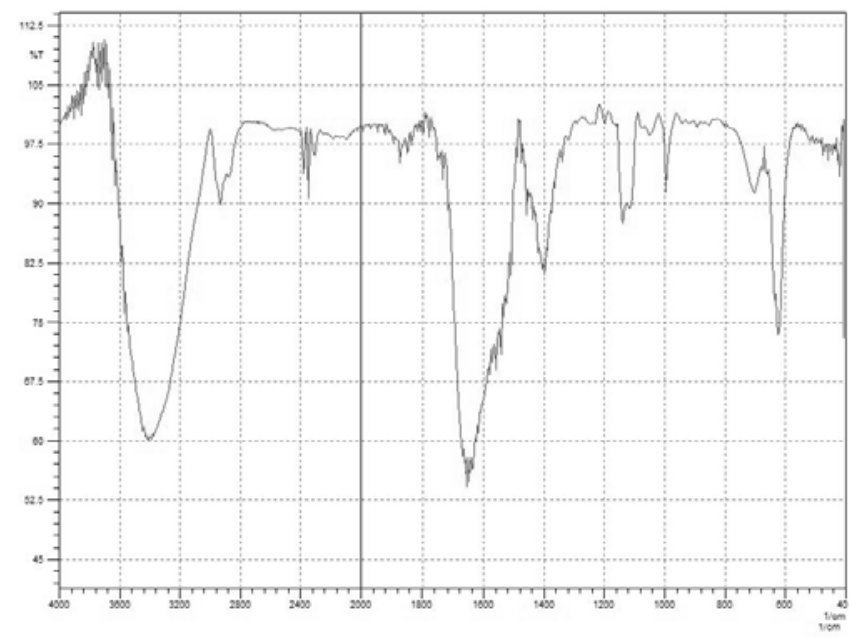

Fig. 1. FT-IR spectra of Fe-soy proteinate.

the coordination of the $\mathrm{C}=\mathrm{O}$ group to the ferrous ion. The XRD spectra of Fe-SP did not show diffraction. These results seem to indicate that Fe-SP exists as amorphous $\mathrm{Fe}$ complexes and does not contain any simple Fe salts, which tend to form a microcrystalline complex. Therefore, the present Fe-SP is considered to be organically chelated Fe source.

Table 3 shows the effects of Fe-SP 100 and Fe-SP 200 supplementation on piglet performance. There were no significant differences among treatments in total number of born or born alive pigs per litter, average birth weight, number of weaned pigs per litter, and weaning weight. Although the birth weight of pigs tended to increase as the level of Fe-SP

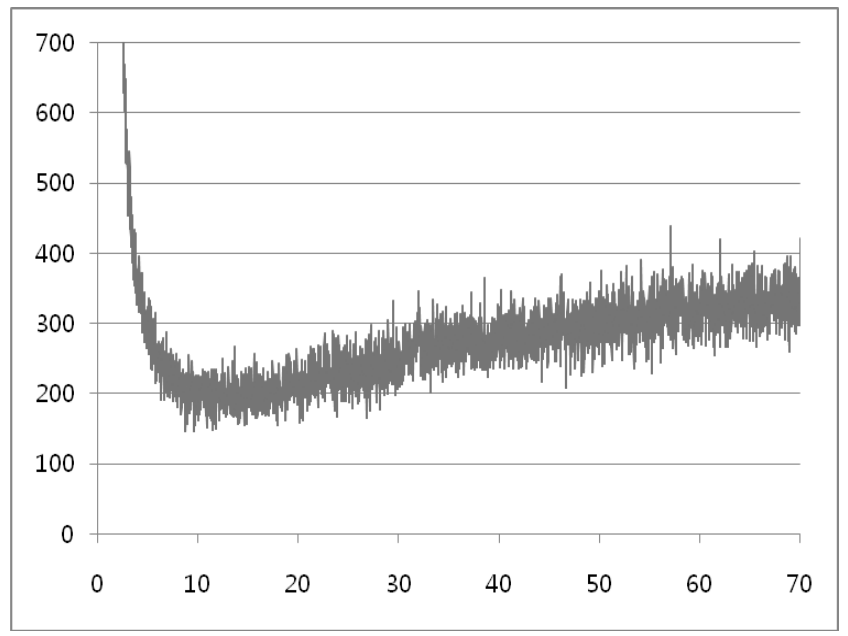

Fig. 2. XRD spectrum of Fe-soy proteinate.

supplementation to sow diet increased, weight gain, feed intake and feed conversion ratio of pigs during $3 \mathrm{wk}$ after birth significantly $(\mathrm{p}<0.05)$ decreased as the level of Fe-SP supplementation increased. It is presumed that palatability of Fe-SP may be low to new born piglets. Low palatability may be the cause of reduced feed intake, weight gain and low feed conversion ratio. There were no significant differences among treatments in Fe concentration in the milk (milk was taken $3 \mathrm{~d}$ after parturition) of sows. However, Fe content in the milk tended to increase as the level of Fe-SP supplementation increased (Table 4). There were no significant differences among treatments in Fe content at $3 \mathrm{wk}$ before parturition in sow blood. However, Fe content at 2 wk

Table 3. Effect of dietary Fe-soy proteinate supplementation on the performance of sows and piglets

\begin{tabular}{|c|c|c|c|c|}
\hline \multirow{2}{*}{ Item } & \multicolumn{3}{|c|}{ Treatments $^{1)}$} & \multirow{2}{*}{$\begin{array}{l}\text { SEM } \\
(n=5)\end{array}$} \\
\hline & Control & Fe-SP 100 & Fe-SP 200 & \\
\hline Number of total pigs born/ litter & 10.40 & 10.50 & 9.60 & 0.431 \\
\hline Number of pigs born alive / litter & 10.20 & 10.50 & 9.60 & 0.419 \\
\hline Average birth wt, kg & 1.30 & 1.40 & 1.47 & 0.054 \\
\hline Number of pigs weaned/litter & 9.40 & 8.50 & 8.40 & 0.709 \\
\hline${ }^{2)}$ Weaning weight, kg / head & 5.67 & 5.08 & 4.73 & 0.217 \\
\hline${ }^{2)}$ Weight gain, kg / head & $4.37^{\mathrm{a}}$ & $3.68^{\mathrm{b}}$ & $3.26^{\mathrm{b}}$ & 0.205 \\
\hline${ }^{3)}$ Feed intake, kg/head/piglet & $6.03^{\mathrm{a}}$ & $4.45^{\mathrm{b}}$ & $3.00^{\mathrm{c}}$ & 1.130 \\
\hline${ }^{3)}$ Feed conversion ratio (FCR) & $1.46^{\mathrm{a}}$ & $1.29^{\mathrm{ab}}$ & $0.93^{\mathrm{b}}$ & 0.067 \\
\hline
\end{tabular}

${ }^{1)}$ Control: sow-basal, piglet-Fe injection; Fe-SP 100: Fe 100 ppm as Fe soy proteinate in sow and piglet diet; Fe-SP 200: Fe 200 ppm as $\mathrm{Fe}$ soy proteinate in sow and piglet diet.

${ }^{2)}$ Weaned at $21 \mathrm{~d}$ after birth.

3) Total feed intake and FCR for $21 \mathrm{~d}$ after birth.

${ }^{\mathrm{a}-\mathrm{c}}$ Means within each row with no common superscript differ $(\mathrm{p}<0.05)$. 
Table 4. Effect of dietary Fe-soy proteinate supplementation on Fe content in sow milk

(mg/L milk)

\begin{tabular}{ccccccc}
\hline \multirow{2}{*}{ Item } & \multirow{2}{*}{ Day } & & Treatments ${ }^{1)}$ & & \multirow{2}{*}{$\begin{array}{c}\text { SEM } \\
(\mathrm{n}=5)\end{array}$} \\
\cline { 3 - 6 } & 3 & Control & Fe-SP 100 & Fe-SP 200 & \multirow{2}{*}{0.493} \\
\hline \hline
\end{tabular}

\footnotetext{
${ }^{1)}$ Control: sow-basal; Fe-SP 100: Fe $100 \mathrm{ppm}$ as Fe soy proteinate in sow diet; Fe-SP 200: Fe 200 ppm as Fe soy proteinate in sow diet.
}

before parturition in sow blood significantly $(\mathrm{p}<0.05)$ increased in Fe-SP supplementation group. While there were no significant differences among treatments in $\mathrm{Fe}$ content at 1 wk before parturition in sow blood, it tended to increase as the supplementation level of Fe-SP increased (Table 5). Control group which had no Fe-SP supplementation to sow diet and had Fe injection $3 \mathrm{~d}$ after birth showed significantly higher Fe content in the blood of pigs at $1^{\text {st }}$ and $2^{\text {nd }}$ wk than Fe-SP supplemented groups. At $3^{\text {rd }}$ wk, however, Fe-SP 200 treatment showed significantly higher Fe concentration in pig blood than others (Table 6). Copper concentrations in the blood of pigs were lower than zinc (Zn) concentration in all treatments. However, concentration of $\mathrm{Zn}$ in the blood at $3^{\text {rd }}$ wk increased significantly as the level of Fe-SP supplementation increased (Table 6). It is well known that aforementioned minerals have strong interactions with one another. Especially, Fe and $\mathrm{Zn}$ had very strong interaction each other. It is expected that divalent mineral ions $(\mathrm{Fe}, \mathrm{Cu}, \mathrm{Zn})$ compete for absorption in intestine. However, $\mathrm{Zn}$ levels of leg muscle and spleen were significantly increased by supplementation of Fe-Met chelate in broiler chickens (Seo et al., 2008). Paik
(2001) reported that approximately $25 \%$ of Cu-Met was dissociated into $\mathrm{Cu}^{2+}$ and methionine ligand when the chelate was dissolved in acidic solution. It is presumed that a certain proportion of Fe-SP may also dissociate in the aqueous condition of intestine. Martine and Scribente (2000) reported that formation constant of $\mathrm{Zn}^{2+}$ with methionine is much greater than that of $\mathrm{Fe}^{2+}$ in $\mathrm{pH}$ 7-9. Free SP ligand liberated from the dissociation of Fe-SP may have bound $\mathrm{Zn}^{2+}$ in the intestine resulting in better absorption. In present study, piglet birth weight was not significantly improved in Fe-SP groups in which Fe-SP was supplemented to sow diets. Ashmead (1993) and Solomon (1997) reported that organic $\mathrm{Fe}$ supplementation may increase the erythrocytes formation, resulting in stabilizing the normal physiological balance, leading to enhancing the performance of pigs. A feeding experiment was conducted by Brady et al. (1978) to evaluate the efficacy and route of transfer of $\mathrm{Fe}$ in a protein hydrolysate chelate of iron $\left(\mathrm{Fe}^{2+}\right)$ from sow to her offspring. The Fe content of the sow milk could be maintained at such levels to prevent anemia by feeding the sow high levels of Fe at any of these periods (gestation-farrowing) (Chaney and

Table 5. Effect of dietary Fe-soy proteinate supplementation on Fe, Cu, and $\mathrm{Zn}$ content in sow blood at different weeks before parturition

\begin{tabular}{|c|c|c|c|c|c|}
\hline \multirow{2}{*}{ Item } & \multirow{2}{*}{$\mathrm{Wks}^{2)}$} & \multicolumn{3}{|c|}{ Treatments $^{1)}$} & \multirow{2}{*}{$\begin{array}{l}\text { SEM } \\
(\mathrm{n}=5)\end{array}$} \\
\hline & & Control & Fe-SP 100 & Fe-SP 200 & \\
\hline \multirow{3}{*}{$\mathrm{Fe}$} & 3 & 345.95 & 369.48 & 344.86 & 20.175 \\
\hline & 2 & $266.19^{c}$ & $366.17^{\mathrm{a}}$ & $325.71^{\mathrm{b}}$ & 6.455 \\
\hline & 1 & 381.73 & 370.89 & 392.42 & 24.873 \\
\hline \multirow{3}{*}{$\mathrm{Cu}$} & 3 & 2.41 & 2.59 & 2.51 & 0.138 \\
\hline & 2 & 2.93 & 2.85 & 2.81 & 0.146 \\
\hline & 1 & 2.82 & 2.41 & 2.72 & 0.255 \\
\hline \multirow{3}{*}{$\mathrm{Zn}$} & 3 & 2.93 & 2.62 & 2.71 & 0.323 \\
\hline & 2 & 2.72 & 2.78 & 2.89 & 0.382 \\
\hline & 1 & 3.74 & 3.19 & 3.62 & 0.453 \\
\hline
\end{tabular}

\footnotetext{
${ }^{1)}$ Control : sow-basal, piglet-Fe injection; Fe-SP 100 :before parturition + after parturition + 3 wks Fe 100 ppm as proteinate in sow and piglet diet; Fe-SP 200 : before parturition + after parturition +3 wks Fe 200 ppm as proteinate in sow and piglet diet.

${ }^{2)}$ Wks: before parturition

${ }^{\mathrm{a}-\mathrm{c}}$ Means within each row with no common superscript differ $(\mathrm{P}<0.05)$.
} 
Table 6. Effect of dietary Fe-soy proteinate supplementation on $\mathrm{Fe}, \mathrm{Cu}$ and $\mathrm{Zn}$ content of piglet blood (mg/L blood)

\begin{tabular}{cccccc}
\hline \multirow{2}{*}{ Item } & wks & \multicolumn{3}{c}{ Treatments $^{1)}$} & $\begin{array}{c}\text { SEM } \\
(\mathrm{n}=30)\end{array}$ \\
\cline { 3 - 5 } & 1 & Control & Fe-SP 100 & Fe-SP 200 & 12.864 \\
\hline \hline \multirow{3}{*}{$\mathrm{Fe}$} & $290.51^{\mathrm{a}}$ & $225.73^{\mathrm{b}}$ & $249.36^{\mathrm{b}}$ & 27.759 \\
& 3 & $517.91^{\mathrm{a}}$ & $290.67^{\mathrm{b}}$ & $468.08^{\mathrm{a}}$ & 26.776 \\
\hline \multirow{3}{*}{$\mathrm{Cu}$} & $362.15^{\mathrm{b}}$ & $373.94^{\mathrm{b}}$ & $576.61^{\mathrm{a}}$ & 0.220 \\
& 2 & 3.30 & 3.49 & 3.51 & 0.345 \\
& 3 & 2.26 & 2.90 & 3.13 & 0.383 \\
\hline \multirow{2}{*}{$\mathrm{Zn}$} & 1 & 2.64 & 3.10 & 2.69 & 0.759 \\
& 2 & 3.52 & 5.10 & 4.03 & 0.518 \\
& 3 & 8.08 & 3.88 & 7.72 & 0.542 \\
\hline
\end{tabular}

${ }^{1)}$ Control: sow-basal, piglet-Fe injection; Fe-SP 100: Fe 100 ppm as Fe soy proteinate in sow and piglet diet; Fe-SP 200: Fe 200 ppm as Fe soy proteinate in sow and piglet diet.

${ }^{\mathrm{a}-\mathrm{c}}$ Means within each row with no common superscript differ $(\mathrm{p}<0.05)$.

Barnhart, 1963; Kim et al., 2009). Thus, piglets from Fepeptide treated sows had higher serum ferritin concentrations even at one week after birth compared to the other groups (Wakabayashi et al., 1989). Based on these results, the supplementation of Fe-peptide to the sow diet in the late stage of pregnancy increased the level of stored Fe (ferritin) not only in the sows but also in newborn piglets (Wakabayashi et al, 1989). Moreover, they also demonstrated that the piglet performance was improved by organic $\mathrm{Fe}$ such as Fe-peptide and ferrous fumarate compared to the control.

In the present study, control group in which $\mathrm{Fe}$ was injected on $\mathrm{d} 3$ showed the highest $\mathrm{Fe}$ concentration in blood at $1^{\text {st }}$ and $2^{\text {nd }}$ wk and then decreased at $3^{\text {rd }}$ wk. On the other hand, Fe-SP supplementation gradually increased and surpassed the control at $3^{\text {rd }}$ wk. Seo et al. (2008) conducted an experiment to determine the efficacy of ironsoy proteinate (Fe-SP) and iron-methionine chelate (Fe-Met) on the performance of laying hens and iron content in egg yolk. Fe content of egg-yolk was effectively increased by supplementing 100 ppm iron as Fe-SP for 5 wk (Seo et al., 2008). Eggshell color significantly improved due to supplementation of Fe-SP 100 (Seo et al., 2010). This result is in good agreement with the results of Park et al. (2004) and Paik et al. (2009). The production index was highest in the Cu-SP 100 group (Seo et al., 2010). Recent information suggests that chelated or complex trace elements may improve the bioavailability of minerals for pigs and poultry.
These metal-amino acid chelates or complexes furnish trace elements that are more efficiently absorbed from the gut than those provided by inorganic salts (Wedekind et al., 1992; Aoyagi \& Baker, 1993). They also provide readily bioavailable amino acids (Wedekind et al., 1992; Aoyagi \& Baker, 1993). Previous reports indicate that some trace minerals in organic form can be utilized better than those of inorganic sources (Seo et al., 2008; Paik et al., 2001). Pesti and Bakalli (1998) reported that dietary supplementation of $250 \mathrm{ppm} \mathrm{Cu}$ in the form of sulfate pentahydrate improved egg production, and Lim and Paik (2003) reported that egg production increased with supplementary $\mathrm{Cu}$ methionine chelate. Methionine is the most commonly used amino acid chelating agent in the preparation of Cu-amino acid chelates. However, methionine is a rather expensive ligand. Thus, CuSP was developed to replace methionine with reduced production costs. In weaned piglets, Carlson et al. (2004) evaluated various supplementation rates of organic $\mathrm{Zn}$ in the form of a proteinate or as a polysaccharide complex, and compared these with $\mathrm{ZnO}$ at 2,000 ppm. Feeding lower concentrations of organic $\mathrm{Zn}$ greatly decreased the amount of $\mathrm{Zn}$ excreted in comparison with inorganic $\mathrm{Zn}$, without loss of growth performance. Veum et al. (2004) studied a $\mathrm{Cu}$ proteinate in weaned pigs in comparison with inorganic $\mathrm{Cu}$ sulfate. Piglet performance was consistently better with organic $\mathrm{Cu}$ at 50 to $100 \mathrm{ppm}$, in comparison with inorganic $\mathrm{Cu}$ at $250 \mathrm{ppm}$. In addition, organic $\mathrm{Cu}$ increased $\mathrm{Cu}$ absorption and retention, and decreased $\mathrm{Cu}$ excretion $77 \%$ 
and 61\% respectively, compared with 250 ppm inorganic Cu. Chelates are organic molecules, normally consisting of 2 organic parts with an essential trace mineral occupying a central position and held in place by covalent bonding.

Based on the data presented above, it could be concluded that supplementation of Fe-SP to periparturient sows may have beneficial effects. However, Fe-SP must be modified to increase palatability to piglets in order to prevent reduced feed intake. If this problem is solved, supplementation of FeSP to piglet diet may be able to replace the common practice of Fe-injection to new born piglets to prevent anemia. This will also enable pig farmers to save time and labor in pig farm.

\section{ACKNOWLEDGEMENTS}

These studies were supported by Industry-University Partnership Laboratory Supporting Business of Korean Small and Medium Business Administration in 2008 (Grants No. 20090512).

It is also acknowledged that the supports of Darby Genetics Inc. and Yuna Pig Production made this experiment possible.

\section{REFERENCES}

AOAC. 1990. Official Method of Analysis (15 ${ }^{\text {th }}$ Ed.). Association of Official Analytical Chemists. Washington, DC, USA.

Ashmead, H. D. 1993. The role of amino acids chelates in animal nutrition. Noyes Publications, New Jersey, USA.

Aoyagi, S. and Baker, D. H. 1993. Protective effect of copperamino acid complexes against inhibitory effects of L-cysteine and ascorbic acid. Poult. Sci. 72 (Suppl. 1) : 82 (Abstr.).

Barber, R. S., Braude, R. and Mitchell, K. G. 1955. Studies on anemia in pigs. I. The provision of iron by intramuscular injection. Vet. Rec. 67:348.

Becker, D. E., Thomas, R. M., Terrill, S. W. and Jensen, A. H. 1960. Sources of iron for the baby pig. AS-528 Mimeograph. III. Swine Grower's Day.

Brady, P. S., Ku, P. K., Ullrey, E. D. E. and Miller, E. R. 1978. Evaluation of an amino acid-iron chelate hematinic for the baby pig. J. Anim. Sci. 47:1135-1140.

Brownlie, W. M. 1955. The treatment of piglet anemia. Vet. Rec. 67:350.

Carlson, M. S., Boren, C. A., Wu, C., Huntington, C. E., Bollinger, D. W. and Veum, T. L. 2004. Evaluation of various inclusion rates of organic zinc either as polysaccharide or proteinate complex on the growth performance, plasma and excretion of nursery pigs. J. Anim. Sci. 28:1359-1366.

Chaney, C. H. and Barnhart, C. E. 1963. Effect of iron supplementation of sow rations on the prevention of baby pig anemia. J. Nutri. 81:187-191.

Doornenbal, H. 1959. The effect of certain oral and injectable iron preparations on the blood of baby pigs. Can. J. Anim. Sci. 39:193-201.

Fouad, M. T. 1976. The physiochemical role of chelated minerals in maintaining optical body biological functions. J. Appl. Nutr. 28:5.

Georgievskii, V. I., Annenkov, B. N. and Samokhin, V. T. 1982. Mineral nutrition of animals. Butterworth-Heinemann Ltd. Oxford, UK.

Han, J. H., Chi, Y. S., Shin, B. K., Kim, S. K. and Paik, I. K. 2006. FT-IR and XRD analyses of commercial methioninemineral chelates. Agric. Chem. Biotechnol. 49:8-10.

Kim, Y. Y., Ha, J. K. and Han, I. K. 2009. Animal nutrition. Han's Animal Science Life Foundation Publications. Seoul, Korea.

Kratzer, F. H. and Vohra, P. 1986. Chelates in nutrition. CRC press, Inc., Boca Raton, FL, USA.

Lim, H. S. and Paik, I. K. 2003. Effect of supplementary mineral methionine chelates $(\mathrm{Zn}, \mathrm{Cu}, \mathrm{Mn})$ on the performance and eggshell quality of laying hens. Asian-Aust. J. Anim. Sci. 16:1804-1808.

Martin, R. and Scribante, P. 2000. Evaluating metal-methionine complexes. Feed International. Watt Publications. Illinois, USA.

Miller, D., Soares, J. H. Jr., Bauersfeld, P. Jr. and Cupett, S. L. 1972. Comparative selenium retention by chicks fed sodium selenit, selenomethionine, fish meal and fish soluble. Poult. Sci. 51:1669-1673.

Naber EC. 1979. The effect of nutrition on the composition of eggs. Poult. Sci. 58:518-528.

NRC. 1998. National research council: nutrient requirement of swine. National Academy Press, Washington DC, USA.

Paik, I. K. 2001. Application of chelated minerals in animal production. Asian-Aust. J. Anim. Sci. 14:191-198.

Paik, I. K., Lee, H. K. and Park, S. W. 2009. Effects of organic iron supplementation on the performance and iron content in the egg yolk of laying hens. J. Poult. Sci. 46:198-202.

Park, S. W., Namkung, H., Ahn, H. J. and Paik, I. K. 2004. Production of Iron Enriched Eggs of Laying Hens. Asian-Aust. J. Anim. Sci. 17:1725-1728.

Pesti, G. M. and Bakalli, R. I. 1998. Sutdies on the feeding 
cupric sulfate pentahydrate to laying hens on egg cholesterol content. Poult. Sci. 77:1540-1545.

Pond, W. G., Lowrey, R. S., Maner, J. H. and Loosli, J. K. 1961. Parenteral iron administration to sows during gestation or lactation. J. Anim. Sci. 20:747-750.

SAS Institute. 2000. SAS system for window V 8.01. SAS Institute Inc., Cary, NC, USA.

Seo, S. H., Lee, H. K., Lee, W. S., Shin, K. S. and Paik, I. K. 2008. The effect of level and prriod of Fe-methionnine chelate supplementation on the iron content of broiler meat. AsianAust. J. Anim. Sci. 10:1501-1505.

Seo, Y. M., Shin, K. S., Rhee, A. R., Chi, Y. S., Han, J. and Paik, I. K. 2010. Effects of dietary Fe-soy proteinate and $\mathrm{MgO}$ on the eggshell quality in laying hens. Asian-Aust. J. Anim. Sci. (In press).

Solomon, S. E. 1997. Egg and eggshell quality. Iowa State University Press.

Spears, J. W. 1992. The bioavailability of zinc, copper and manganese amino acid complexes and chelates. NFIA, Nutrition Institute.

Steel, R. G. D. and Torrie, J. H. 1980. Principles and procedures of statistics. A biometrical approach. $2^{\text {nd }}$ ed. McGraw-Hill Book Co., New York, NY, USA.

Veum, T. L., Carlson, M. S., Wu, C. W., Bollinger, D. W. and Ellersieck, M. R. 2004. Copper proteinate in weanling pig diets for enhancing growth performance and reducing fecal copper excretion compared with copper sulfate. J. Anim. Sci. 82:1062-1070.

Wahlstrom, R. C. and Juhl, E. W. 1960. A comparison of different methods of iron administration on rate of gain and hemoglobin level of the baby pig. J. Animal Sci. 19:183-188.

Wakabayashi, T., Yamamoto, M., Hirai, Y. and Yoshino, Y. 1989. Absorption and availability of iron peptide in pregnant sows. Zootech. Coll., No. 38. 93-105.

Wedekind, K. J., Hortin, A. E. and Baker, D. H. 1992. Methodology for assessing zinc bioavailability: efficacy estimates for zinc-methionnine, zinc sulfate, and zinc oxide. J. Anim. Sci. 70:178-187.

Zoubek, G. L., Peo, E. R. Jr., Moser, B. D., Stahly, T. and Cunningham, P. J. 1975. Effects of source on copper uptake by swine. J. Anim. Sci. 40:880-884.

(Received June 4, 2010; Revised June 11, 2010; Accepted June 14, 2010) 